http://jmscr.igmpublication.org/home/

ISSN (e)-2347-176x ISSN (p) 2455-0450

crossref DOI: https://dx.doi.org/10.18535/jmscr/v7i7.76

\title{
Incidence of wound infection post subcuticular suturing versus simple suturing a comparative study in KMC, Katihar
}

\author{
Authors

\begin{abstract}
Dr Shakeb Ahmad", Dr Md. Abdur Rahman², Dr Yasir Tajdar ${ }^{3}$, Dr Ankita Sharma4,
\end{abstract} \\ Dr Sunil Kumar ${ }^{5}$, Dr Shashank Saurav ${ }^{6}$, Dr Tuba Yazdani ${ }^{7}$ \\ ${ }^{1}$ Associate Professor, Dept. of Gen. Surgery, KMC \\ 2,3,4,5,6,7 Junior Resident, Dept. of Gen. Surgery, KMC
}

\begin{abstract}
To prevent SSI post surgery is an important aim after every surgery. There are two methods of wound closure technique i.e. simple wound closure and subcuticular suturing which is cosmetically better suturing technique. A prospective non-randomized study of 100 patients with surgical wound was carried out over a period of 12 months(June 2018 to June 2019) in 50 patients (group A), wound closure was done with simple interrupted method and in 50 patients(group B) with subcuticular method. This study was done in Katihar medical college, Katihar. Data including age, sex, wound infection, wound type were collected. $3 \%$ of patients in group A and $2 \%$ in group B had wound infection. Wound type of $65 \%$ of the group $A$ and $58 \%$ of patients in the group B were clean contaminated. 42 percent of patients in group $A$ and $36 \%$ of patients in group B are located in the age of 21 to 40 years. $74 \%$ of group $A$ and $70 \%$ of group B were male. Surgical site of $88 \%, 1 \%, 2 \%$ and $9 \%$ of patients in group A and $80 \%, 2 \%, 10 \%$ and $8 \%$ of patients in group $B$ was in abdomen, thorax, head and neck and extremity, respectively. Incidence of wound infection in patients who had surgical wounds sutured by subcuticular and simple were $8 \%$ and $4 \%$, respectively that this difference was not statistically significant. Therefore in our study it depicts that subcuticular suturing is having better aesthetic result. In our study, the incidence of wound infection was lower than other studies.
\end{abstract}

Keywords: Infection, simple, subcuticular.

\section{Introduction}

The degree of bacterial contamination during an operation is related to the risk of incisional infections ${ }^{[1]}$. Good suturing technique should eliminate dead space in subcutaneous tissues, minimize tension that causes wound separation. It involves correct wound placement with respect to relaxed tension lines ${ }^{[2]}$. Simple suture, it is the most fundamental technique of wound closure used in cutaneous surgery. In this procedure the needle enters one side of the wound and penetrates well into the dermis or subcutaneous tissue. By altering the depth or angle of the needle, one can use this technique for wound edges of uneven thickness. The needle is then passed through the subcutaneous tissue to the opposing side of the wound and exists closer to the wound edge so that the final configuration of the suture is flask-shaped ${ }^{[3,4,5]}$. Another method for suture is subcuticular stitches, the subcuticular stitch is started by inserting a knot at one end of the incision. A small bite is taken of the 
subcuticular material and the suture is pulled through. Then on the opposite side of the wound a similar subcuticular bite of the suturing material is inserted and gently worked up the wound. The subcuticular suture is used primarily to enhance the cosmetic results ${ }^{[6]}$. The aim of this study was to compare the incidence of wound infection between the two groups of patients that their wound are sutured by subcuticular or simple interrupted procedure.

\section{Material and Method}

A prospective non-randomized study of 100 patients with surgical wound was carried out over a period of 12 months(June 2018 to June 2019) in 50 patients (group A), wound closure was done with simple interrupted method and in 50 patients (group B) with subcuticular method. The study was conducted in Katihar Medical College, Katihar. Data including age, sex, wound infection, wound type was considered. The correlation between the variables was done by IBM SPSS statistics 18 .

\section{Result}

$3 \%$ of patients in group A and 2\% in group B had wound infection. All wound infections occurred in the first weeks. Wound type of $65 \%$ of the group $\mathrm{A}$ and $58 \%$ of patients in the group B were clean contaminated. $42 \%$ of patients in group $\mathrm{A}$ and $36 \%$ of patients in group B were located in the age of 21 to 40 years. $74 \%$ of group A and $70 \%$ of group B of patients were male. $3 \%$ and $1 \%$ of patients in group A and $4 \%$ and $2 \%$ of the group B had diabetes and took steroids, respectively. Surgical site of $88 \%, 1 \%, 2 \%$ and $9 \%$ of patients in group $\mathrm{A}$ and $80 \%, 2 \%, 10 \%$ and $8 \%$ of patients in group B were in abdomen, thorax, head and neck and extremity, respectively.

\section{Discussion}

To prevent SSI post surgery is an important aim after every surgery. Effective skin closure is a necessary factor in the prevention of infection ${ }^{[7]}$. More patients in both groups in our study were male (group A and B). The number of patients were maximum in the age group of 21 to 40 years in both the groups. Subcuticular suturing provides a better result as no skin interruption is caused by the suturing tool, and better blood flow is maintained $^{[8]}$. This technique is used in the areas where better cosmetic results are required i.e. the exposed areas most commonly demanded by the female patients. The subcuticular suture does not impact on deep tissues of the skin and leads to minimal strangulation of tissue ${ }^{[9]}$. A previous study has reported that subcuticular method do not increase the infection rate ${ }^{[10]}$ like in our study. Incidence of wound infection in our patients for which of these two techniques (subcuticular and simple) had been used were $3 \%$ and $2 \%$, that their values were much lower than previous study. Chisquare test did not show significant relationship in the incidence of wound infection in two techniques (simple and subcuticular) ( $\mathrm{P}$ value $<0.05)$.

\section{Conclusion}

Incidence of wound infection in patients who had surgical wounds sutured by subcuticular and simple were $3 \%$ and $2 \%$, respectively that this difference was not statistically significant. Therefore, we recommend the routine use of subcuticular method in surgical wound closure with better aesthetic result.

\section{Bibliography}

1. Grant SW, Hopkins J, Wilson SE; Operative site bacteriology as an indicator of postoperative infectious complications in elective colorectal surgery. Am Surg., 1995; 61(10):856-61.

2. Borges AF; Techniques of wound suture. Elective Incisions and Scar Revision. Boston: Little Brown., 1973;65-76.

3. Kudur MH, Pai SB, Sripathi H, Prabhu S; Sutures and suturing techniques in skin closure. Indian J Dermatol Venereol Leprol., 2009;75:425-34. 
4. Moy RL, Waldman B, Hein DW; A review of sutures and suturing techniques. J Dermatol Surg Oncol., 1992;18:785-95.

5. Zachary CB; Suture techniques. In: Zachary CB, editor. Basic Cutaneous Surgery. New York: Churchill Livingstone., 1991;53-75.

6. Moy RL, Lee A, Zalka A; Commonly used suturing techniques in skin surgery. American Family Physician., 1991;44(5): 1625-34.

7. Sakka SA, Graham K, Abdulah A; Skin closure in hip surgery: subcuticular versus transdermal. A prospective randomized study. Acta Orthop Belg., 1995;61(4):3316.

8. Zografos GC, Martis K, Morris DL;Laser Doppler flowmetry in evaluation of cutaneous wound blood flow using various suturing techniques. Ann Surg., 1992; 215(3):266-8.

9. Fiennes AG; Interrupted subcuticular polyglactin sutures for abdominal wounds. Ann R Coll Surg Engl., 1985;67:121.

10. Corder AP, Schache DJ, Farquharson SM, Stephen GT; Wound infection following high saphenous ligation. A trial comparing two skin closure techniques: Subcuticular polyglycolic acid and interrupted monofilament nylon mattress sutures. Journal of the Royal College of Surgeons of Edinburgh., 1991;36(2):100-2.

11. Gilmore OJA., Martin TDM; Aetiology and prevention of wound infection in appendectomy. Br. J. Surg., 1974; 61(4):281-87.

12. Foster GE, Hardy EG, Hardcastle JD; Subcuticular suturing after appendicectomy. Lancet., 1977;1(8022): 1128-9. 